\title{
To See or Not to See: Importance of Sensemaking in Employee Self-direction'
}

I Gisela Bäcklander ${ }^{2}$

PhD candidate, Industrial Economics and Management, KTH Royal Institute of Technology, Stockholm, Sweden

\begin{abstract}
Being self-directed is one of the most sought-after employee attributes. The present study examines managers' approaches to and conceptualization of employee self-directedness through semi-structured interviews with 13 managers from five companies in the Stockholm area. Analysis suggests two different emphases in trying to increase self-direction, with differing underlying assumptions: an evaluation emphasis where self-direction is conceptualized as an inherent property of the individual, and a cultivation emphasis suggesting a more interactionist perspective of selfdirection as an emergent behavior based on the interaction of individual and situational characteristics. Further, a 'seeing work'-skill emerged in all interviews, implicating situational judgment and attention as core to what is ultimately seen as successful self-direction. Managers with a cultivation emphasis mentioned as viable tactics those focused on supporting sensemaking and thus enriching the working situation to enable better discretionary situational judgments.
\end{abstract}

\section{KEYWORDS}

Implicit follower theories / knowledge work / proactive behavior / self-direction / selfleadership / sensemaking / Sweden / ICT industry / thematic analysis

\section{Introduction}

o be competitive and innovate faster, organizations are increasingly expecting employees to take initiative and to manage themselves (Belschak \& Hartog 2010; Busck et al. 2010; Erdogan \& Bauer 2005; Muhr et al. 2012; Seibert et al. 2001; Thomas et al. 2010). Part of the Nordic competitive advantage has long been cooperative and 'pliable' organizations with skilled and autonomous employees contributing their creativity and agency (Kasvio et al. 2012). The increased pace of change in organizational environments implies that the value of explicit prescriptions for jobs is declining. Such prescriptions soon become outdated, inflexible, and counterproductive. At the same time, many jobs are becoming boundaryless in terms of where, when, and how work should be done (Allvin et al. 2013; Aronsson 2018), especially for knowledge workers (Donnelly 2006; Ipsen \& Jensen 2010). Consequently, the regulation of work is becoming a task for the individual herself - from external boundaries and organizing to individual, internal boundaries and organizing (Hanson 2004). On almost all fronts, delimitations around work seem to have become less explicit in terms of what the actual task is, as well as

\footnotetext{
${ }^{1}$ You can find this text and its doi at https://tidsskrift.dk/njwls/index.

${ }^{2}$ Corresponding author: Gisela Bäcklander, KTH Royal Institute of Technology, INDEK, Lindstedtsvägen 30, s-100 44 Stockholm, Sweden. E-mail: gisela.backlander@indek.kth.se
} 
when, where, how, and with whom to perform it (Allvin et al. 2013). When employees face so-called 'weak situations' (Mischel 1977) - unclear job or role prescriptions, vague task descriptions, uncertain divisions of responsibility - employee autonomy is more valuable and relates to better performance (Cordery et al. 2010). Accordingly, skills related to leading and regulating oneself have become increasingly important (Hanson 2004; Hvid 2009; Muhr et al. 2012; Neck \& Houghton 2006; Seibert et al. 2001; Thomas et al. 2010).

This is reflected in the fact that during hiring, employers seek candidates who manage these demands well. Swedish recruiting consultancy service Academic Work, which mainly places young knowledge workers, asked customers to rate the top three most important characteristics in the selection of candidates, and the top two were 'self-directing' and 'structured'. Young professionals, on the other hand, highly value a good introduction and being 'well taken care of' in jobs they seek (Academic Work, 2012, personal communication).

To the extent that external boundaries and directions for work do not exist, the employee herself needs to employ some kind of strategy or approach in order to structure her work (Hanson 2004; Hvid et al. 2008), coordinate efforts with others (Grant \& Parker 2009), and craft her own role (Kira et al. 2010; Wrzesniewski \& Dutton 2001). In short, the employee needs to be self-directed to a much higher degree.

The aims of the present study, based on semi-structured interviews with managers and HR people in Information and Communications Technology (ICT) and consulting, are to examine how managers conceptualize employee self-direction, how they recognize it, and how the conceptualization informs what strategies they deem viable to increase it.

\section{Theoretical background}

\section{From follower to proactive self-leader}

A growing literature has focused on the role of 'followers' in the leader-follower dyad and how followers influence and co-create leadership (Blom \& Alvesson 2014; Carsten et al. 2010; DeRue \& Ashford 2010) as well as manage themselves (Manz 2015). Carsten et al. (2010) found that followers' views of themselves could be cast on a continuum of passive - active - proactive follower. 'Passive followership' was characterized by emphasizing loyalty, following orders, and deferring to the leader's knowledge and expertise. 'Active followership' meant offering opinions when given the opportunity, but not proactively identifying needs and responding to them without prompting from a leader. 'Proactive followers', on the other hand, saw their role as 'working to advance the mission of their department or organization' and to challenge their leaders if necessary (Carsten et al. 2010). The researchers concluded that the proactive followers could actually be construed as leaders, as they regulated their own behavior [self-leadership (Manz 1986)], led other team members [shared leadership (Pearce \& Conger 2003)], practiced upward influence (Deluga and Perry 1991), and overall used influence to create change toward a common purpose - that is, they were leading, albeit not from a top-down position.

Conceptualizations of proactiveness such as proactive personality (Bateman $\&$ Crant 1993), personal initiative (Fay \& Frese 2001), and proactive behavior (Parker 
et al. 2006) have been studied quantitatively and show positive effects on, among other things, job performance (Crant 1995), innovation (Denti et al. 2013), career success (Seibert et al. 1999), and newcomer integration (Cooper-Thomas et al. 2014). However, as expectations for employees to fulfil the role of 'proactive follower' or 'selfleader' are increasing (e.g., Campbell 2000; Neck \& Houghton 2006; Thomas et al. 2010), some researchers have taken an interest in possible drawbacks or costs of such behavior.

\section{Self-leadership is not everything - making sense of situations}

For the individual, being proactive often means doing more at work and working longer hours (Bergeron et al. 2014), and may lead to job stress, role overload, and work-life conflict (Bolino \& Turnley 2005). Campbell (2000) has described an 'initiative paradox', where employers say they want initiative from employees but nonetheless punish it if it is seen as applied in the wrong direction. For employees who perform less well, proactive behavior such as seeking feedback may actually hurt them because managers tend to see this as impression-management, a manipulative behavior, rather than performanceenhancing behavior (De Stobbeleir et al. 2010).

Further, the organizational expectation of proactivity or self-directed behaviors in employees may incur costs to the organization itself. Bolino, Valcea, and Harvey (2010) suggest that organizations expect proactive employee behavior will 'fill the void' created by the withdrawal of active leadership. Withdrawal of leadership to the point of socalled laissez-faire leadership (Bass \& Avolio 1990) may cause role conflict, role ambiguity, and coworker conflict (Skogstad et al. 2007). Withdrawal of active leadership in favor of expecting proactivity may cause organizations to be overly dependent on specific individuals and undermine the socialization of new employees, the organization's capacity for learning, and the development of new leaders (Bolino et al. 2010).

Highlighting the importance of not eroding organizational culture and the socialization of new employees, some studies have examined interaction effects of proactivity and the ability to act in situationally appropriate ways. One study (Chan 2006) found that proactive personality had a positive relationship with job performance, job satisfaction, and organizational commitment when situational judgment effectiveness (SJE) was high, but a negative relationship when SJE was low. For individuals with high degrees of alignment with organizational values and skills to fit their jobs, a proactive personality is related to positive work outcomes but not for those with lower person-organization or person-job fit (Erdogan \& Bauer 2005).

On the basis of this literature, it seems that if expectations of employee self-directedness result in a withdrawal of leadership, it may negatively affect employees' ability to make sense of their situations in ways that will lead them to nonetheless act to benefit the organization.

Sensemaking has been conceptualized in different ways (Maitlis \& Christianson 2014; Sandberg \& Tsoukas 2015; Weick 1995) but generally converges on a process through which organizational members 'extract and interpret cues from their environment, using these as the basis for a plausible account that provides order and "makes sense" of what has occurred, and through which they continue to enact the environment' (Maitlis \& Christianson 2014). The exact nature of 'sense' being made 
has been defined as 'intellectual grasp', 'perception', 'meaningfulness', and 'reflection' (Weick 1995: 24-25). Sensemaking is triggered when a situation is novel, ambiguous, or uncertain - but one could argue that in judging a situation as novel or unexpected, sensemaking has already begun. Indeed, Sandberg and Tsoukas (2015) introduced the concept of 'immanent sensemaking', reflecting a more mundane and ubiquitous sensemaking than the more commonly examined episodic and exceptional sensemaking, for example, in a crisis. I believe this more mundane sensemaking relates more to the kind of situational judgment described by Chan (2006). Through sensemaking, a situation will be construed and interpreted in some way and acted upon as if it was some thing, and after the fact the action taken can be interpreted in turn by an observer (e.g., a manager) as indicative of, for example, better or worse judgment, more or less accurate and appropriate action. In this sense, situational judgment is more of a 'product' or outcome (and it is usually measured as such), while sensemaking is a process producing actions that can be evaluated. That any observer's evaluation of actions should be privileged is of course not reflecting any inherent 'truth' but simply reflecting the fact that, in organizations, managers typically have more power to evaluate employees than the other way around; and of course, especially in the setting of this study where I have interviewed employer representatives about employees and about hiring, an explicitly evaluative situation.

\section{Managers' implicit theories of followers}

Beliefs about the nature of proactivity and self-directedness will likely affect what approaches are favored to promote it. How managers attribute reasons and motives for their followers' behaviors, so-called Implicit Follower Theories (IFTs), affect whether the behavior is viewed favorably or unfavorably (De Stobbeleir et al. 2010; Sy 2010), which in turn may affect leadership behaviors such as willingness to offer coaching (Heslin et al. 2006). This is in line with a view of leadership and followership as socially coconstructed phenomena negotiated on an ongoing basis through interplay among actors (Carsten et al. 2010; Fairhurst \& Grant 2010), making perceptions critical. Leaders and followers both use implicit theories to make sense of and react to others' behaviors and thus create the conditions for further interactions (Shondrick \& Lord 2010). With this perspective, a key to understanding how employee self-directedness might be increased is to understand how leaders see their own role in enabling it, in turn informed by their conceptualizations of it. For this reason, I have chosen not to go into the study with a ready-made conceptualization of 'self-directedness' but rather explore participants' own definitions and boundaries of the phenomenon of employee self-directedness, how it is recognized, and how it might be increased [phenomenon-driven research, PDR (Schwarz \& Stensaker 2014)].

\section{Methods}

The study was conducted in Stockholm, Sweden, in the spring of 2013 in cooperation with five large (400-200,000 employees) knowledge-intensive organizations whose participants had agreed that self-direction in employees was important and valued. 


\section{Participants}

Participating organizations were selected because they contained people who could likely provide rich information on the topic of self-direction among knowledge workers, so-called purposive sampling (Ritchie et al. 2013).

A letter describing the purpose and conditions of the study was sent to personal contacts in HR departments of organizations in the Stockholm area, or directly to managers, except in one case. In this case, first contact was made on Twitter after a person in this organization blogged about how they practice servant leadership, a kind of leadership related to and thought complementary to self-leadership (van Dierendonck 2011). Seven organizations were approached with the study information; one chose to decline participation and one did not answer, leaving five organizations that contributed with one or more participants, and a total of 13 respondents. Participants were aged 27-52 $(M=38$ years) and had between 5 and 25 subordinates $(M d n=8)$. Three participants were women. In cases where the organization was not as a whole in IT or IT consulting, respondents were chosen from IT/technology/engineering departments. See a summary of participants in Table 1 .

Table I Study participants

\begin{tabular}{|c|c|c|c|c|}
\hline Organization & Role & Designation & Age & Direct reports \\
\hline Retail clothing & IT project manager & $|\mathrm{P}|$ & 39 & 12 \\
\hline IT consulting & Head of recruitment & IP2 & 52 & 7 \\
\hline IT consulting & Department manager & IP7 & 38 & 15 \\
\hline IT consulting & Department manager & IP8 & 38 & 25 \\
\hline Software development & Agile coach & IP3 & 38 & 0 \\
\hline Software development & Team lead & IP4 & 35 & 6 \\
\hline Software development & Team lead & IP5 & 27 & 10 \\
\hline Consulting & Department manager & IP6 & 39 & 20 \\
\hline Financial tech & Department manager & IP9 & 43 & 7 \\
\hline Financial tech & Manager & IPIO & 37 & 8 \\
\hline Financial tech & Manager & $|P| \mid$ & 33 & 10 \\
\hline Financial tech & Manager & $|\mathrm{P}| 2$ & 46 & 5 \\
\hline Financial tech & Manager & $\mathrm{IPI}$ & 27 & 7 \\
\hline
\end{tabular}

\section{Data collection}

A qualitative approach with semi-structured interviews was used for data collection. Interview questions were created on the topics of describing self-direction and self-leadership, how one can distinguish between who is self-directing and who is not, whether self-direction is a personal characteristic or something situational, why self-direction is important or necessary for their organization, and if and how they try to promote it in their organizations. Respondents were encouraged to use detailed, concrete examples in their answers and when applicable to think of specific people and situations to illustrate what they mean. This was done in order to ground the data material in episodic memory - to 
start with what respondents remember happening and doing, rather than what they think they 'know' (Shondrick et al. 2010) and to avoid the use of 'management speak' in the data itself (Alvesson \& Sveningsson 2003). However, participants were also asked to explain what they were trying to achieve by doing certain things, exploring motivations, attributions, and causal inferences made by participants - thus assuming they are 'knowledgeable agents' who know what they want to do and are capable of explaining their intentions and actions (Gioia et al. 2013). Interviews were conducted in Swedish or English as applicable by this author at the respondents' place of work and scheduled for 1 hour each. Sound was recorded digitally and transcribed by the researcher after each organizational visit.

\section{Data analysis}

Transcripts were coded manually in NVivo 9, a software for qualitative data analysis. Analysis followed the thematic analysis framework presented by Clarke, Braun, and Hayfield (2015). A scaffolding of codes was created before coding based on Strauss's (1987) suggestion of coding for 'conditions', 'interactions among actors', 'strategies and tactics', and 'consequences' and further broken down into subcodes based on the topics in the interview guide. New codes were added inductively while coding, mainly as sub codes to the existing structure, to cover emerging themes (Bryman \& Burgess 2002). Examples of such themes were "“seeing” work', 'self-direction as characteristic', and 'clarifying boundaries'.

After an initial coding round, all interviews were analyzed again to add or recode as necessary, as new codes had been added organically while going through the material. Next, high-level codes were analyzed one by one, and the hierarchy of the codes themselves was reconsidered. Conceptual maps were drawn to capture ideas of causality in the material.

Analysis was based on finding patterns, recurring themes, and concepts, which were interpreted and related to the research aims and to theory. Results were written up as narratives representative of what was not only said in relation to themes dictated by the research questions but also in relation to what were considered emergent topics such as the "sseeing work" skill' and alternative meanings or more self-interested themes also present in their statements upon reflexion. Illustrative quotes from the interviews were selected based on deemed representativeness. These written results with illustrative quotes form the basis for the following findings. Quotes have been translated to English in this paper where applicable.

\section{Findings}

In this section, I begin by addressing how managers conceptualize 'self-directed employee' and why this is desired. Then, I address findings about how managers conceptualize their own role in increasing self-direction.

\section{How managers conceptualize the 'self-directed employee' and why it is desired}

Participants' reasons for why self-directedness is important could be described as boiling down to efficiency in three ways: (a) quickly adapting to change; (b) optimal use 
of managers' time; and (c) optimal use of expertise. See Table 2 for illustrative quotes. This shows that managers construe the need for self-directed employees as strategically important, contributing to organizational adaptability, and efficient use of resources: both their own time and skills, and those of employees. But more self-serving motives could also be seen in their statements. Most participants explicitly stated a preference for not having to micromanage or 'handhold' employees [see Table 2 (d)]. Such hands-on direction did not seem congruent with the kind of leader they wanted to be, nor was it something they enjoyed doing. Further, the preference for more self-directed employees seemed grounded in a feeling that it was just easier. Less autonomous individuals meant 'more work' for the manager or 'more time away' from other, more enjoyable, tasks which, again, was seen as both organizationally inefficient and not fun.

Descriptions of the behaviors of self-directed employees span both in-role and extrarole behaviors, and expectations of these seemed to follow seniority. Junior employees were more expected to focus on learning their role well and to take responsibility for that learning. For example, if they encountered problems, they were expected to 'flag' that they needed help so they could quickly move on, rather than wait or rely on being monitored. What Carsten et al. (2010) has described as the 'passive followership' role was not really considered acceptable any stage. Interestingly, some behaviors that were seen as a sign of proactivity in junior employees were described as problematic when done by non-junior employees. Asking for directions or flagging were accepted as self-directedness in junior employees, but in non-junior employees, asking for a lot of direction was sometimes seen

Table 2 Findings and illustrative quotes answering how self-direction is conceptualized

\section{Findings Illustrative quote}

\section{Reasons why self-directedness is important and desired:}

(a) Quickly adapting to change

'If you have self-leading employees /.../You'll have a group steering towards the target at all times instead of a group that grinds to a halt every time something unexpected happens.' [IPI]

(b) Optimal use of manager's 'So for me, if I have to do too much hands on management and drive time people it takes too much time away from other places. It takes away from my own time and my ability to be efficient.' [IPI3]

(c) Optimal use of expertise 'It is always those who sit close to the details who are in reality and see the actual things, so they probably have the best idea of what doesn't work. /.../The effect is that even though I am helping, the results are still worse. /.../ If I didn't work on those things like last year, I'm not going to be able to give the best answer.' [IPIO]

(d) Personal preferences

'I'm not like that as a manager either. I don't like to knock on peoples' backs and ask did you do this, did you do that. /.../ I am not that kind of manager.' [IP2]

'I am not one of those who wants to GIVE work tasks and we don't have the capacity as an organization to manage, or rather micromanage, what people do.' [IP5]

\section{Behavioral content of 'self-directedness':}

(e) Flagging
'I can't be monitoring things so closely that I will know whenever there's a holdup. So for that reason it's very important to have people that, when they have a couple of hours free, will actively come to me and say "hey, I need more to do".' [IPI] 
Table 2 (Continued)

\begin{tabular}{|c|c|}
\hline Findings & Illustrative quote \\
\hline (f) 'Seeing' work & $\begin{array}{l}\text { 'A person who does this well, sees what it is she should do at all times } \\
\text { and just does it, and does it quickly and professionally' [IP6] } \\
\text { 'They mustn't need being told each day what to do but be able to create } \\
\text { their own job or see what the job is.' [IP7] }\end{array}$ \\
\hline (g) Negotiating with others & $\begin{array}{l}\text { 'It could be the case that "oh, I can't make progress on this problem } \\
\text { because I'm blocked by something another team is responsible for". Then } \\
\text { we want you to go to that team and inform them, talk to them.' [IP3] }\end{array}$ \\
\hline $\begin{array}{l}\text { (h) Strategic, e.g., thinking long- } \\
\text { term, setting direction }\end{array}$ & $\begin{array}{l}\text { 'If you feel like something else is more important to do above the priori- } \\
\text { ties that I set, because it aligns better with our vision, then you do that. } \\
\text { You are supposed to do that, I expect you to do that.' [IPI I] } \\
\text { 'You make sure to solve the problem once and for all, you create a frame- } \\
\text { work other teams can re-use, you go out in the organization to evangelize } \\
\text { it' [IP5] }\end{array}$ \\
\hline
\end{tabular}

\section{Insufficient self-direction:}

(i) Too high need for direction 'He hears me saying that he needs to be more proactive /.../ but he seems to have a hard time doing it. He's still like "but what does that mean, can we list together what I should do?" - but the point of being self-managing is that we shouldn't have to list together, me and him, the things that he should do' [IP6]

as not being self-directed enough and requiring too much managerial time and monitoring. Illustrated in Table 2, an employee asking the manager to help him list things he should do to be more self-directed frustrates the manager, as she believes that this is exactly opposite to the point of being self-directed. Ideally, she wanted him to be able to extract or 'see' what to do after being exposed to the same information as everybody else in a weekly meeting, for example, not needing special attention after such a meeting. All respondents described an ability similar to this 'seeing': seeing what problems there are, seeing what needs to be done, seeing how one can contribute, seeing how to give best value, seeing what is more important right now. This was wanted and expected mostly from somewhat more experienced workers. It was not elaborated upon as a required skill explicitly, but several of the interviewees did use the verb 'see' in a similar fashion to describe what it was self-directed employees were doing. When asked to describe an employee who was good at self-directing, one manager says it is one who must not be told each day what to do 'but be able to create their own job or see what the job is'.

To sum up, managers' describe that the best self-directed employees not only solve given tasks, but they are also capable of seeing or creating the work that they need to do, they understand problems to a degree such that they can create long-term solutions that can scale, and they mentor their peers and propagate their great work inside their organizations (see Table 2).

\section{How managers conceptualize viable ways of increasing self-directedness}

Although all participants were in agreement that self-directedness was a desired employee behavior, they tended to emphasize different approaches as viable for 
increasing self-directedness. One approach, which we may call evaluation, was concerned mainly with fit; specifically, judging whether employees were a good fit for the organization and possessing the right qualities. This meant first concern in recruiting them (select in) and thereafter in pruning those evaluated as bad fits (select out). The other emergent approach we may call cultivation (Knee 1998) where the emphasis is more on how to 'grow' or 'develop' the sought-after qualities in the organization. Simply put, once an employee is inside the organization they are no longer so much evaluated as cultivated. Managers' different conceptualizations of viable approaches reveal something about their implicit theories of self-directedness as either an inherent trait to be selected for, or as an emergent behavior that is possible when conditions are favorable. In turn, such a view has implications for where responsibilities lie for accomplishing self-directed employee behaviors and whether and how managers think of themselves as co-creators in this. See Table 3 for a brief summary of the approaches, each of which will be explored in more depth below.

\section{SD as personal characteristic $\rightarrow$ Evaluation and fit concerns}

A kind of sink-or-swim approach was illustrated by one of the organizations. The organization was described by all its participants as very free, with little structure but great opportunities to do interesting work. The organization's lack of orienting signals is made apparent by this manager describing her own work:

'How it is here now - it's not super clear. /.../ I know our main areas of responsibilities. But there are definitely parts of it where I am unsure if they are really my responsibilities or not, and I don't really know who could answer that question either to be completely honest.' [IP12]

Table 3 A summary of conceptualization of viable approaches to increase employee self-direction (SD)

\begin{tabular}{|c|c|c|c|c|}
\hline Approach & Attribution & $\begin{array}{l}\text { How to } \\
\text { promote SD }\end{array}$ & $\begin{array}{l}\text { View of } \\
\text { non-SD }\end{array}$ & $\begin{array}{l}\text { Dealing with } \\
\text { insufficient SD }\end{array}$ \\
\hline Evaluation & $\begin{array}{l}\text { SD is something you } \\
\text { either have or you } \\
\text { don't; a personal } \\
\text { characteristic that is } \\
\text { transferrable between } \\
\text { contexts }\end{array}$ & $\begin{array}{l}\text { Hire the right people } \\
\text { based on interviews. } \\
\text { Try to get rid of bad } \\
\text { fits. }\end{array}$ & $\begin{array}{l}\text { Indicative of bad fit } \\
\text { with organization, } \\
\text { as the organization } \\
\text { requires SD. }\end{array}$ & $\begin{array}{l}\text { Be explicit that SD } \\
\text { is expected. 'Don't } \\
\text { complain - solve the } \\
\text { problem'. Push to } \\
\text { another department. }\end{array}$ \\
\hline Cultivation & $\begin{array}{l}\text { SD needs both } \\
\text { individually internal } \\
\text { factors (mainly will } \\
\text { and interest) and ex- } \\
\text { ternal factors such as } \\
\text { opportunity, support, } \\
\text { and clarity }\end{array}$ & $\begin{array}{l}\text { Structured intro- } \\
\text { duction and pairing } \\
\text { up. Enable through } \\
\text { transparent informa- } \\
\text { tion, being clear about } \\
\text { expectations. Avoid } \\
\text { micromanagement. }\end{array}$ & $\begin{array}{l}\text { Indicative that the } \\
\text { employee may lack } \\
\text { motivation, interest, } \\
\text { or understanding } \\
\text { of the situation and } \\
\text { priorities. }\end{array}$ & $\begin{array}{l}\text { Be clear about } \\
\text { boundaries and areas } \\
\text { of responsibility. En- } \\
\text { courage peer helping. } \\
\text { Give a nudge in the } \\
\text { right direction. Do not } \\
\text { punish initiative. Might } \\
\text { monitor more closely. }\end{array}$ \\
\hline
\end{tabular}


She does not have a clear option for escalating concerns or asking someone else for help as she does not know who might have the answers she needs. With little guidance from explicit procedures or informal network knowledge (knowing who-knows-what), the individual herself still has to be capable of deciding what to do and how. If you cannot do that, the organization's focus is not on teaching you how but rather, as another manager explains, that this organization is 'not for you':

'That is one of the things I tell people in interviews: this is not a company that suits everyone. If you want to work in a structured environment, something which is calm and you understand what your job is /.../ - that is not [Financial Tech].' [IP11]

All participant organizations used evaluation to increase self-directedness during hiring by looking for signs of being self-directed. However, some emphasized 'having it' more than in the cultivation approach. As an example, one manager said of hiring:

'it's a character trait./.../ If they're self-motivated you don't need to do anything.' [IP11]

What really distinguished evaluation, however, was what happens when employees, after being hired, are not sufficiently self-directing. One manager explains how he handles employees who are less self-directed than the ideal:

'I typically try to push them to other departments, which I have successfully done. In America I would fire them.' [IP13]

To conclude, managers with a heavy evaluation emphasis attribute self-directed behavior in employees mostly to personal characteristics and are more likely to judge behavior to indicate 'fit' between employee and organization.

\section{$\mathrm{SD}$ as interaction $\rightarrow$ Nurture and cultivation concerns}

Managers with a heavier cultivation emphasis spoke much more of ways to develop self-directed behaviors inside the organization, indicating a more interactionist attribution model. None of the respondents thought that personality was entirely unrelated to behavior; however, some emphasized the will and interest to develop self-direction more than in the evaluative approach. Talking about what they are looking for when hiring in relation to self-direction, managers described:

'It's the attitude we want from our consultants, that they want to do this. /.../Having that attitude and ambition.' [IP7]

'At least having the inclination - that you're prepared or want to work that way. We sometimes hire directly from university so you definitely get the opportunity to learn it here.' [IP3]

The main ways of onboarding were mandatory introduction courses, 'boot camps' where new employees work in teams to do training tasks while learning the systems and whom to talk to, and buddy systems where the new employee is paired with a more experienced person in the same role. 
Sending employees on courses to improve their skills was believed to help with self-direction, as simply being better at something would allow you to manage it better without seeking help. However, self-direction was itself seen as a learnable skill: interviewees from two different organizations mentioned sending employees to time management training.

Managers talked of ways to offer opportunity, support, and clarity to develop selfdirection on a more ongoing basis, that is, they spoke more of their own behavior and responsibilities, as well as the work context needed for self-direction to emerge. They did not simply focus on 'training' individuals. Avoiding micromanagement was commonly brought up as absolutely essential for nurturing employee self-direction.

'I have to practice what I preach of course, not just saying one thing and then scolding someone for how they solved a problem or micro-monitoring what they did. If I did, that individual would not be as self-directed, if he got punished for trying something on his own.' [IP1]

Respondents claimed they had neither the time or interest to micromanage anyone and control everything. However, monitoring emerged as both a kind of fallback solution when necessary and something somewhat stealthily (though not maliciously) done to keep an eye on things without appearing to do so. Two managers admitted that the most common solution when an employee was not being sufficiently self-directed was to more closely monitor this person and to prompt them for status reports more often. Somewhat self-critically, one said that this was probably not a good solution for developing self-directive skills in the employee long-term. Even when no performance problems were apparent, several managers mentioned nevertheless keeping an eye on employees, especially if they were new or had displayed problems with overworking and stress, a kind of paternalistic monitoring motivated both by care for employees' well-being, and their productivity.

Respondents mentioned several activities related to bringing clarity to the working situation. Being open and transparent with information was mentioned as a way of facilitating employees' own prioritizing.

And setting expectations in various ways: telling employees what they are supposed to achieve or explicitly explaining that it is their responsibility to create their own tasks or to make progress in some area, was also thought to decrease ambiguity. Software development interviewees, especially, stressed that not only is it your job to do your task as you think is best but also to invent that task, to see what you should be working on to create the best value. A few managers thought it of great importance that each person knows exactly what their areas of responsibility are, and that this is a necessary condition for being able to be proactive.

'Of course it is in relation to given areas of responsibility and delimitations. You need some direction and awareness of what you're supposed to do, otherwise it's difficult to be self-going, you need certain preconditions.' [IP6]

This perspective certainly contrasts the sink-or-swim attitude in a more evaluative approach. 


\section{Discussion}

This study set out to answer how managers conceptualize self-direction in employees and why it is needed, as well as how they see their own role in approaches to increase or strengthen it. Findings show that managers desire self-directed employees to increase organizational adaptiveness and to optimize use of the manager's own time and expertisebasically to avoid wasting time doing for employees what they should be able to do for themselves. These findings echo the literature that attributes practices of decentralizing power and decision-making responsibilities to a greater need for flexibility, rapid response capabilities, and better use of implicit knowledge (Bottrup et al. 2008; Wall et al. 2002: 147). The study also shows that successful 'employee self-direction' as conceptualized by managers is more than proactive behaviors such as taking charge or using voice it also involves making adequate sense of situations and information. A theme emerging as core to successful self-direction was 'seeing work' - the ability to 'just see' or conceive of work tasks for oneself that one ought to prioritize without being explicitly instructed about a task or even being prompted to do the 'seeing' of work. This implicates situational judgment as core to what is ultimately seen as successful self-direction. In both English and Swedish (interviews were conducted in both languages), the word 'seeing' is used as a metaphor for 'understanding' and for perceiving more generally (Jonas 1954; Styhre 2010). In a paper on Swedish leadership, which they describe as indirect and vague, Holmberg and Åkerblom (2001) quote a typical turn of phrase from Swedish managers, directed at employees, 'See what you can do about it!' as a way of mandating employees to solve a problem. Also key to the emergent concept of 'seeing' is action, by necessity: managers do not have access to employees' private thoughts but can observe and interpret their action as signals of having understood, or 'seen' something that they should do. The theoretical concept of sensemaking seems to capture this same dynamic of acting-understanding: seeing a situation as something and acting upon it, in such a way as to after the fact being deemed good situational judgment. Previous research on proactive employee behavior has similarly noted that proactive employees seem to 'see' opportunities (for acting) more often than others, which may also lead to them doing more and risk overload more easily (Bergeron et al. 2014). The self-directed employee then is first someone who is more sensitive and responsive to cues for (personal) action, second someone who will make prudent choices about how to act (as judged by, in this context, their manager) on those cues. Viewed this way, it seems possible for organizational actors, included but not limited to managers, to influence 'self-direction' also by what cues are salient in the environment and through schemas for interpreting cues (Bäcklander 2019: 14-15).

Sensemaking refers to how we impose some structure on ambiguous situations so as to make them actionable (Weick et al. 2005). In knowledge work especially, it has been pointed out that a central problem is identifying what the task is (Drucker 1999), or perhaps, rather, to construct what the task is. Several Nordic scholars have noted this expectation of translating fluctuating demands (from 'the market' in the form of the customer (Allvin et al. 2006), 'users', 'stakeholders', society) into manageable, more concrete demands in their specific job (e.g., Bosch-Sijtsema et al. 2009; Bottrup et al. 2008; Hanson 2004; Kira \& Forslin 2008; Nurmi 1998). Filling in the gaps in an underspecified, 'weak' situation was described by participants as employees 'just seeing' what work needed to be done, or even 'creating work' for themselves (see Table 2 for examples). 
Although 'just seeing' sounds immediate and easy, if it did not happen and instead fell on managers to do, it was framed as 'more work' and 'handholding', that is, something time-consuming and laborious, something that had to be constructed and which did not exist ready-made.

Related to the concept of self-direction it has been pointed out that increased autonomy or lack of job confinement does not equal control over work (Busck et al. 2010; Grönlund 2007; Hvid 2009), that is, it may include little control over work demands. While market demands are not bureaucratically processed and turned into neatly parceled tasks, knowledge workers may nevertheless be expected to 'infer' demands (Bäcklander et al. 2018), estimate time consumption for projects and out-bid one another (Tynell 2002), and proactively anticipate and adapt to new demands (Allvin et al. 2006; Maravelias 2007). 'Seeing work' then seems to be an ability and not least a willingness to interpret and translate new information into work demands, relate them to individual strengths and knowledge, and craft tasks out of it. To the extent that this does work, it is easy to see how valuable it is for making organizations 'pliable' and cooperative as has been the Nordic ideal (Kasvio et al. 2012).

However, simply having information in front of you does not mean you will be able to make sense of it, as evidenced in one story of insufficient self-direction where an employee was at the same meeting as everyone else and yet was not deemed to 'see' what the information in the meeting meant for what he should be doing next. Inability to make sense of demands, capabilities, and contexts are signs of information overload. Rather than just having 'too much' data, the load becomes excessive because it is incomprehensible. Sensemaking can act as a buffer to overload (Sutcliffe $\&$ Weick 2008). In Weick's (1993) description of a collapse of sensemaking, loss of meaning (informal structure, shared interpretive schemes) and loss of frameworks (rules, procedures, authority relations) cause each other in a deviation-amplifying loop. When a situation makes inadequate sense to the employee described in Table 2 (i), he cannot act on what he has not perceived as a call to action. Instead, he seeks to inform himself better - rather proactively, one might say - by relying on frameworks and seeking help from the manager. When she is reluctant to give it, he may go into a spiral where the job makes less and less sense and he takes less and less self-directed action, or relies more and more on being monitored and checked by a supervisor. For a more junior employee, interview responses generally indicated it would have been ok to ask for specific directions without hurting one's image as self-directed.

That managers judge employees' (in)action after-the-fact as good, bad, aligned, or not does not mean that there were 'hidden' work tasks 'out there' to be uncovered. Employees are not just to grasp existing intentions for work tasks but are instrumental in constructing meaning and tasks. In confining the organizational experience a certain way and acting on it, employees not only show themselves to be 'self-directing' in alignment with some order but also create order, possibly leading to a reinforcing spiral where the co-created context makes more sense to them, and also similar sense to others such as their managers. The self-directed employee 'creates the story' (Colville et al. 2012) through which her actions will be interpreted.

Unpacking the concept of 'self-directed' affects how we interpret the approaches managers claim to use to increase self-direction. Both evaluation and cultivation approaches create conditions for self-directed behaviors by creating 'room' for them, not having heavy bureaucracies or a lot of top-down, hands-on management - so-called 
controlling environments (London \& Smither 1999). However, when it comes to the sensemaking component of self-direction, a cultivation approach offers explicit activities for socialization, orientation, and learning - for example, boot camps, clear ways of escalating responsibilities, transparency in motives and information, and setting expectations - while this was not emphasized in the evaluation approach. Furthermore, proactive sensemaking activities such as asking questions or seeking clarifications seemed easily to be interpreted as a sign of mismatch with an evaluation emphasis. Taking it a step further, consider the possible consequences for sensemaking when some lines of inquiry are effectively closed off by making them interpersonally risky to pursue (Edmondson \& Lei 2014), as they might be interpreted as demonstrating a 'bad fit'. Asking for help is both proactive (Lee 1997) and a learning behavior (Edmondson 1999). Help seekers can be considered contributing to organizational sensemaking as they proactively define and frame problems, search for experts and connect with them - that is, they play an active role and are not only passive receivers of help as they are sometimes characterized (Lee 1997). However, if people perceive help seeking as risky in a particular context, they will not do it (Edmondson \& Lei 2014; Lee 1997). Emphasizing 'bad fit' evaluations of employees will likely not promote the psychological safety (Edmondson 1999) conducive to proactive ways of enriching situational judgment for all employees. As a result, organizational coordination of work will likely suffer (Pennanen \& Mikkola 2016).

Those speaking with a more cultivation emphasis not only went beyond selection but also beyond 'training', which is still a very individualistic perspective on performance (Carroll et al. 2008; Fenwick 2001: 54). While training is about increasing skills or knowledge of the individual, with a cultivation emphasis, achieving employee self-direction can be seen as a dynamic interactive process between manager, employee, coworkers, available information and frames of reasoning, and so on. Being self-directed was, for these managers more than others, not seen as a matter of (only) skill but of opportunity, of trusting it would not be punished, and of seeing affordances for action.

This study contributes to a stream of research emphasizing the relevance of situational strength and context for understanding the emergence of desired employee behaviors (Judge \& Zapata 2015; Meyer et al. 2010). More specifically, it contributes to literature on proactive behavior by showing how managers' implicit theories about followers contribute to different work contexts that may be more or less open to employees' attempts to proactively enrich their situational understanding and thereby achieve the combination of good judgment and initiative that will be interpreted as the 'selfdirectedness' that organizations desire. The Nordics, and Sweden especially, have a long tradition of 'responsible autonomy' for employees, self-steering work groups (Amble 2013), and a consensus culture (Holmberg \& Åkerblom 2001). But these have grown out of a context of work that has been quite highly designed, or prescribed, for example, car assembly at Volvo (Sandberg 1995). Today, more and more of the Nordic workforce, especially Sweden, are engaged in Knowledge Intensive Activities (KIA) (Eurostat 2018). The more ambiguous, higher degrees-of-freedom, 'weak situations' of knowledge work may present a case where the problem is less about having more or less autonomy and control but rather what opportunities autonomous employees have for navigating the organization, making sense of their work, and 'seeing' meaningful tasks for themselves in the flow of information at work. To reach simultaneous goals of employees acting on their own and alignment with organizational vision and mission, both autonomy and

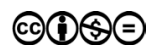


sensemaking supports are needed. A view of self-directedness as emerging in interaction seemed more including of ways to support sensemaking such as stabilizing boundaries and offering explicit learning situations.

\section{Limitations}

As this paper argues for the importance of context, the limits of the study's generalizability should be noted. Participants all come from the ICT sector where they manage either software developers or consultants, and they work mainly in the geographical area of Stockholm, Sweden. Stockholm has been called 'the startup capital of Europe' and has the second most billion-dollar ICT companies per capita in the world (The Telegraph 2015). Thus, when the interviews were conducted, being a manager in the ICT sector would generally mean looking forward to a growing job market, being well paid, and having a general sense of positive buzz around the kind of work one is doing. Scandinavian work culture is characterized by low power differences, 'flat' hierarchies, and placing high value on employee involvement, self-direction and autonomy (Enehaug 2017; Lindeberg et al. 2013). This study may therefore be most interesting as an example of organizations on the extreme end (Flyvbjerg 2006) of desiring self-directed employees, rather than as indicative of organizations in general.

Further, the sample itself is small. The range of views may therefore perhaps be wider in a larger sample, or one more representative of several industries (see, e.g., Bolander et al. 2014, demonstrating three general approaches to talent management in Sweden). The emergent finding of the 'seeing work'-skill as central to self-direction was however mentioned, spontaneously, by every participant. The centrality of seeing, and its conceptual link with sensemaking, may therefore be more likely to generalize outside of the study than perhaps the Evaluation and Cultivation views on selfdirectedness.

\section{Conclusions and future research}

Being self-directed is one of the most sought-after employee attributes. The present study has focused on managers' approaches to and conceptualization of employee selfdirectedness. The analysis suggests mainly two different emphases in trying to increase self-direction, with differing underlying assumptions: an evaluation emphasis where selfdirection is conceptualized as an inherent property of the individual, and a cultivation emphasis suggesting a more interactionist perspective of self-direction as an emergent behavior based on the interaction of individual and situational characteristics. Further, the emergent topic of the 'seeing work'-skill implicates situational judgment as core to what is ultimately seen as successful self-direction. Those with a cultivation emphasis mentioned as viable tactics those focused on supporting sensemaking and thus enriching the working situation to enable better discretionary situational judgments. The centrality of 'seeing work' highlights the importance of situational judgment and attention, to self-direction. Exploring the role of the environment, and ways to proactively choose or modify the environment, to succeed in self-direction from the individual's own perspective warrants further research. Future research could also consider especially the 
situations where non-junior employees are considered not sufficiently self-directed and how to best break that negative cycle. Could managers be taught to consider employees' direction seeking differently? Should employees seek clarity from peers instead? While one might be tempted to think that these employees simply do not have enough information, Sutcliffe and Weick (2008) warn that it is not the amount so much as the sense that is insufficient. Would assigning someone the role of asking 'dumb questions' for the benefit of everyone help enrich situations with more sense? This and other ways to 'build in' more opportunities for sensemaking into daily work might make situations less ambiguous without adding rigidity or bureaucracy, enabling action that is at once discretionary and sufficiently aligned with organizational goals.

\section{References}

Allvin, M., Aronsson, G., Hagström, T., Johansson, G., and Lundberg, U. 2006. Gränslöst arbete: Socialpsykologiska perspektiv på det nya arbetslivet (Boundaryless work: Social psychology perspectives on the new working life), Stockholm: Liber.

Allvin, M., Mellner, C., Movitz, F., and Aronsson, G. (2013). The diffusion of flexibility: estimating the incidence of low-regulated working conditions, Nordic Journal of Working Life Studies 3(3): 99. doi: https://doi.org/ 10.19154/njwls.v3i3.3013.

Alvesson, M., and Sveningsson, S. (2003). Good visions, bad micro-management and ugly ambiguity: contradictions of (non-) leadership in a knowledge-intensive organization, Organization Studies 24(6): 961-988. doi: https://doi.org/ 10.1177/0170840603024006007.

Amble, N. (2013). Autonomy and control when working with humans-A reflection on sociotechnical concepts, Nordic Journal of Working Life Studies 3(4): 44-61. doi: https://doi. org/ 10.19154/njwls.v3i4.3072.

Aronsson, G. 2018. Gränslöst arbete - En forskarantologi om arbetsmiljöutmaningar i anknytning till ett gränslöst arbetsliv (Boundaryless work - A research anthology about work environment challenges in connection to a boundaryless work life), Stockholm: Arbetsmiljöverket. Available at: https://www.av.se/globalassets/filer/publikationer/ rapporter/granslost-arbete-en-forskarantologi-om-arbetsmiljoutmaningar-i-anknytning-till-ett-granslost-arbetsliv rap2018 1.pdf.

Bass, B. M., and Avolio, B. J. 1990. 'The implications of transactional and transformational leadership for individual, team, and organizational development.' in R W Woodman and W A Pasmore (eds.), Research in organizational change and development, Greenwich, CT: JAI Press.

Bateman, T. S., and Crant, J. M. (1993). The proactive component of organizational behavior: A measure and correlates, Journal of Organizational Behavior 14(2): 103-118. doi: https://doi.org/ 10.1002/job.4030140202.

Belschak, F. D., and Hartog, D. N. (2010). Pro-self, prosocial, and pro-organizational foci of proactive behaviour: Differential antecedents and consequences, Journal of Occupational and Organizational Psychology 83(2): 475-498. doi: https://doi.org/ 10.1348/096317909X439208.

Bergeron, D. M., Schroeder, T. D., and Martinez, H. A. (2014). Proactive personality at work: seeing more to do and doing more?, Journal of Business and Psychology, 29(1): 71-86. doi: https://doi.org/ 10.1007/s10869-013-9298-5.

Blom, M., and Alvesson, M. (2014). Leadership on demand: followers as initiators and inhibitors of managerial leadership, Scandinavian Journal of Management 30(3): 344-357. doi: https://doi.org/ 10.1016/j.scaman.2013.10.006. 
Bolander, P., Asplund, K., and Werr, A. (2014). Talent Management in a Collectivistic and Egalitarian Context-The Swedish Case, SSE/EFI Working Paper Series in Business Administration.

Bolino, M. C., and Turnley, W. H. (2005). The personal costs of citizenship behavior: the relationship between individual initiative and role overload, job stress, and work-family conflict, Journal of Applied Psychology 90(4): 740. doi: https://doi.org/ 10.1037/00219010.90.4.740.

Bolino, M. C., Valcea, S., and Harvey, J. (2010). Employee, manage thyself: The potentially negative implications of expecting employees to behave proactively, Journal of Occupational and Organizational Psychology 83(2): 325-345. doi: https://doi.org/ 10.1348/ 096317910X493134.

Bosch-Sijtsema, P. M., Ruohomäki, V., and Vartiainen, M. (2009). Knowledge work productivity in distributed teams, Journal of Knowledge Management 13(6): 533-546. doi: https://doi.org/ 10.1108/13673270910997178.

Bottrup, P., Kamp, A., and Nielsen, K. T. (2008). Selvteknologier-magt og styring i det ny arbejde. (Self technologies - power and control in the new work), Tidsskrift for arbejdsliv, 10(1): 5-9.

Bryman, A., and Burgess, B. 2002. Analyzing Qualitative Data, New York: Routledge.

Busck, O., Knudsen, H., and Lind, J. (2010). The transformation of employee participation: consequences for the work environment, Economic and Industrial Democracy, 31(3): 285-305. doi: https://doi.org/ 10.1177/0143831X09351212.

Bäcklander, G. (2019). Doing complexity leadership theory: how agile coaches at Spotify practise enabling leadership, Creativity and Innovation Management, 28(1): 42-60. doi: https://doi.org/ 10.1111/caim.12303.

Bäcklander, G., Rosengren, C., and Kaulio, M. (2018). Managing intensity in knowledge work: self-leadership practices among Danish management consultants, Journal of Management \& Organization: 1-19. doi: https://doi.org/ 10.1017/jmo.2018.64.

Campbell, D. J. (2000). The proactive employee: Managing workplace initiative, Academy of Management Perspectives, 14(3):52-66.doi: http://doi.org/10.5465/AME.2000.4468066.

Carroll, B., Levy, L., and Richmond, D. (2008). Leadership as Practice: Challenging the Competency Paradigm, Leadership, 4(4): 363-379. doi: https://doi.org/ 10.1177/1742715008095186.

Carsten, M. K., Uhl-Bien, M., West, B. J., Patera, J. L., and McGregor, R. (2010). Exploring social constructions of followership: a qualitative study, The Leadership Quarterly 21(3): 543-562. doi: https://doi.org/ 10.1016/j.leaqua.2010.03.015.

Chan, D. (2006). Interactive effects of situational judgment effectiveness and proactive personality on work perceptions and work outcomes., Journal of Applied Psychology 91(2): 475-481. doi: https://doi.org/ 10.1037/0021-9010.91.2.475.

Clarke, V., Braun, V., and Hayfield, N. 2015. 'Thematic analysis.' in J Smith (ed.), Qualitative Psychology: A Practical Guide to Research Methods, London: Sage.

Colville, I., Brown, A. D., and Pye, A. (2012). Simplexity: sensemaking, organizing and storytelling for our time, Human Relations 65(1): 5-15. doi: https://doi.org/ 10.1177/0018726711425617.

Cooper-Thomas, H. D., Paterson, N. L., Stadler, M. J., and Saks, A. M. (2014). The relative importance of proactive behaviors and outcomes for predicting newcomer learning, well-being, and work engagement, Journal of Vocational Behavior 84(3): 318-331. doi: https://doi.org/ 10.1016/j.jvb.2014.02.007.

Cordery, J. L., Morrison, D., Wright, B. M., and Wall, T. D. (2010). The impact of autonomy and task uncertainty on team performance: a longitudinal field study, Journal of organizational behavior, 31(2-3): 240-258. doi: https://doi.org/10.1002/job.657. 
Crant, J. M. (1995). The Proactive Personality Scale and objective job performance among real estate agents, Journal of Applied Psychology 80(4): 532. doi: https:/doi.org/ 10.1037/0021-9010.80.4.532.

De Stobbeleir, K. E., Ashford, S. J., and Sully de Luque, M. F. (2010). Proactivity with image in mind: How employee and manager characteristics affect evaluations of proactive behaviours, Journal of Occupational and Organizational Psychology 83(2): 347-369. doi: https://doi.org/ 10.1348/096317909X479529.

Deluga, R. J., and Perry, J. (1991). The relationship of subordinate upward influencing behaviour, satisfaction and perceived superior effectiveness with leader-member exchanges, Journal of Occupational and Organizational Psychology 64(3): 239-252. doi: https://doi. org/ 10.1111/j.2044-8325.1991.tb00557.x.

Denti, L., Hemlin, S., and Mumford, M. (2013). Leadership and innovation: a cross-cultural study of mediating psychological processes, Academy of Management Proceedings 2013(1): 14300-14500. doi: https://doi.org/ 10.5465/AMBPP.2013.197.

DeRue, D. S., and Ashford, S. J. (2010). Who will lead and who will follow? A social process of leadership identity construction in organizations, Academy of Management Review 35(4): 627-647. doi: https://doi.org/ 10.5465/amr.35.4.zok627.

Donnelly, R. (2006). How 'free' is the free worker? An investigation into the working arrangements available to knowledge workers, Personnel Review 35(1): 78-97. doi: https:// doi.org/ 10.1108/00483480610636803.

Drucker, P. F. (1999). Knowledge-Worker Productivity: The Biggest Challenge. California Management Review, 41(2), 79-94. doi: 10.2307/41165987.

Edmondson, A. C. (1999). Psychological safety and learning behavior in work teams, Administrative Science Quarterly, 44(2): 350-383. doi: https://doi.org/ 10.2307/2666999.

Edmondson, A. C., and Lei, Z. (2014). Psychological safety: the history, renaissance, and future of an interpersonal construct, Annual Review of Organizational Psychology and Organizational Behavior 1(1): 23-43. doi: https://doi.org/ 10.1146/annurevorgpsych-031413-091305.

Enehaug, H. (2017). Ten successful years: a longitudinal case study of autonomy, control and learning, Nordic Journal of Working Life Studies 7(S2): 67-89. doi: https://doi.org/ 10.18291/njwls.v7iS2.96693.

Erdogan, B., and Bauer, T. N. (2005). Enhancing career benefits of employee proactive personality: The role of fit with jobs and organizations, Personnel Psychology 58(4): 859891. doi: https://doi.org/ 10.1111/j.1744-6570.2005.00772.x.

Eurostat. 2018. Employment in Knowledge Intensive Activities (KIA) as \% of total employment.

Fairhurst, G. T., and Grant, D. (2010). The social construction of leadership: a sailing guide, Management Communication Quarterly 24(2): 171-210. doi: https://doi.org/ $10.1177 / 0893318909359697$.

Fay, D., and Frese, M. (2001). The concept of personal initiative: an overview of validity studies, Human Performance 14(1): 97-124. doi: https://doi.org/ 10.1207/ S15327043hup1401 06.

Fenwick, T. J. (2001). Work knowing 'on the fly': enterprise cultures and co-emergent epistemology, Studies in Continuing Education 23(2): 243-259. doi: https://doi.org/ 10.1080/01580370120101993.

Flyvbjerg, B. (2006). Five misunderstandings about case-study research, Qualitative Inquiry 12(2): 219-45. doi: https://doi.org/ 10.1177/1077800405284363.

Gioia, D. A., Corley, K. G., and Hamilton, A. L. (2013). Seeking qualitative rigor in inductive research, Organizational Research Methods 16(1): 15-31. doi: https://doi.org/ 10.1177/1094428112452151. 
Grant, A. M., and Parker, S. K. (2009). 7 Redesigning work design theories: the rise of relational and proactive perspectives, Academy of Management Annals 3(1): 317-375. doi: https://doi.org/ 10.5465/19416520903047327.

Grönlund, A. (2007). Egenkontroll som friskfaktor och riskfaktor. Det gränslösa arbetet i Västeuropa och Sverige (Control as salutogenic factor and risk factor. Boundaryless work in Western Europe and Sweden), Arbetsmarknad \& Arbetsliv 13(2): 11-25.

Hanson, M. 2004. Det flexibla arbetets villkor-om självförvaltandets kompetens (Selfgoverning competence for flexible work). In Arbetsliv i omvandling 2004:8, Stockholm: Arbetslivsinstitutet.

Heslin, P. A., Vandewalle, D., and Latham, G. P. (2006). Keen to help? Managers' implicit person theories and their subsequent employee coaching, Personnel Psychology 59(4): 871-902. doi: https://doi.org/ 10.1111/j.1744-6570.2006.00057.x.

Holmberg, I., and Åkerblom, S. (2001). The production of outstanding leadership — an analysis of leadership images in the Swedish media, Scandinavian Journal of Management 17(1): 67-85. doi: https://doi.org/ 10.1016/S0956-5221(00)00033-6.

Hvid, H. S. (2009). To be in control: Vejen til godt psykisk arbejdsmiljø, læring og innovation? (To be in control: The road to a good psychological work environment, learning and innovation?), Tidsskrift for arbejdsliv (1): 11-30.

Hvid, H. S., Lund, H., and Pejtersen, J. (2008). Control, flexibility and rhythms, Scandinavian Journal of Work Environment \& Health (6): 83-90.

Ipsen, C., and Jensen, P. L. (2010). Causes of work-related stress and individual strategies in knowledge work, DTU Management Engineering. Department of Management Engineering-The Technical University of Denmark. Lyngby, Denmark: 1-32.

Jonas, H. (1954). The nobility of sight, Philosophy and Phenomenological Research, 14(4): 507-519. doi: https://doi.org/ 10.2307/2103230.

Judge, T. A., and Zapata, C. P. (2015). The person-situation debate revisited: Effect of situation strength and trait activation on the validity of the Big Five personality traits in predicting job performance, Academy of Management Journal 58(4): 1149-1179. doi: https://doi.org/ 10.5465/amj.2010.0837.

Kasvio, A., Gonäs, L., and Skorstad, E. J. (2012). In search of the Nordic working life model; introduction to the thematic issue, Nordic Journal of Working Life Studies 2(4): 1.

Kira, M., and Forslin, J. (2008). Seeking regenerative work in the post-bureaucratic transition, Journal of Organizational Change Management 21(1): 76-91. doi: https://doi.org/ 10.1108/09534810810847048.

Kira, M., van Eijnatten, F. M., and Balkin, D. B. (2010). Crafting sustainable work: development of personal resources, Journal of Organizational Change Management 23(5): 616-632. doi: https://doi.org/ 10.1108/09534811011071315.

Knee, C. R. (1998). Implicit theories of relationships: assessment and prediction of romantic relationship initiation, coping, and longevity, Journal of Personality and Social Psychology 74(2): 360. doi: https://doi.org/ 10.1037//0022-3514.74.2.360.

Lee, F. (1997). When the going gets tough, do the tough ask for help? Help seeking and power motivation in organizations, Organizational Behavior and Human Decision Processes 72(3): 336-363. doi: https://doi.org/ 10.1006/obhd.1997.2746.

Lindeberg, T., Månson, B., and Larsen, H. H. (2013). 'HRM in Scandinavia-Embedded in the Scandinavian Model?' in E. Parry, E. Stavrou and M. Lazarova (eds.), Global Trends in Human Resource Management, London: Springer.

London, M., and Smither, J. W. (1999). Empowered self-development and continuous learning, Human Resource Management 38(1): 3-15. doi: https://doi.org/ 10.1002/(SICI)1099050X(199921)38:1<3::AID-HRM2>3.0.CO;2-M. 
Maitlis, S., and Christianson, M. (2014). Sensemaking in organizations: taking stock and moving forward, The Academy of Management Annals 8(1): 57-125. doi: https:/doi.org/ 10.1080/19416520.2014.873177.

Manz, C. C. (1986). Self-leadership: toward an expanded theory of self-influence processes in organizations, Academy of Management Review 11(3): 585-600. doi: https://doi.org/ 10.5465/amr.1986.4306232.

Manz, C. C. (2015). Taking the self-leadership high road: smooth surface or potholes ahead?, Academy of Management Perspectives 29(1): 132-151. doi: https://doi.org/ 10.5465/ amp.2013.0060.

Maravelias, C. (2007). Freedom at work in the age of post-bureaucratic organization, Ephemera: Theory \& Politics in Organization 7(4): 555-574.

Meyer, R. D., Dalal, R. S., and Hermida, R. (2010). A review and synthesis of situational strength in the organizational sciences, Journal of Management 36(1): 121-140. doi: https://doi.org/ 10.1177/0149206309349309.

Mischel, W. 1977. 'The interaction of person and situation.' in David Magnusson and Norman S. Endler (eds.), Personality at the Crossroads: Current Issues in Interactional Psychology, Hillsdale, N. J.: Lawrence Erlbaum Associates.

Muhr, S. L., Pedersen, M., and Alvesson, M. 2012. 'Workload, aspiration, and fun: Problems of balancing self-exploitation and self-exploration in work life.' in Mikael Holmqvist, André Spicer (ed.) Managing 'Human Resources' by Exploiting and Exploring People's Potentials (Research in the Sociology of Organizations, Volume 37), Emerald Group Publishing Limited. doi: https://doi.org/10.1108/S0733-558X(2013)0000037011.

Neck, C. P., and Houghton, J. D. (2006). Two decades of self-leadership theory and research, Journal of Managerial Psychology 21(4): 270-295. doi: https://doi.org/ 10.1108/02683940610663097.

Nurmi, R. (1998). Knowledge-intensive firms, Business Horizons 41(3): 26-32. doi: https:// doi.org/ 10.1016/s0007-6813(98)90005-2.

Parker, S. K., Williams, H. M., and Turner, N. (2006). Modeling the antecedents of proactive behavior at work, Journal of Applied Psychology 91(3): 636-652. doi: https://doi.org/ 10.1037/0021-9010.91.3.636.

Pearce, C., and Conger, J. 2003. Shared Leadership: Reframing the Hows and Whys of Leadership, Thousand Oaks, CA: SAGE Publications.

Pennanen, E., and Mikkola, L. (2016). Work coordination as a social interaction process in nursing staff meetings 2016, 6(2): 19. doi: https://doi.org/ 10.19154/njwls.v6i2.4970.

Ritchie, J., Lewis, J., Nicholls, C. M., and Ormston, R. 2013. Qualitative Research Practice: A Guide for Social Science Students and Researchers, London: Sage.

Sandberg, J., and Tsoukas, H. (2015). Making sense of the sensemaking perspective: its constituents, limitations, and opportunities for further development, Journal of Organizational Behavior 36(S1): S6-S32. doi: https://doi.org/ 10.1002/job.1937.

Sandberg, Å. 1995. Enriching Production. Perspectives on Volvo's Uddevalla Plant as an Alternative to Lean Production, Brookfield, WI: Avebury: Arbetslivsinstitutet.

Schwarz, G., and Stensaker, I. (2014). Time to take off the theoretical straightjacket and (re-)introduce phenomenon-driven research, The Journal of Applied Behavioral Science, 50(4): 478-501. doi: https://doi.org/ 10.1177/0021886314549919.

Seibert, S. E., Crant, J. M., and Kraimer, M. L. (1999). Proactive personality and career success., Journal of Applied Psychology 84(3): 416-427. doi: https://doi.org/ 10.1037/00219010.84.3.416.

Seibert, S. E., Kraimer, M. L., and Crant, J. M. (2001). What do proactive people do? A longitudinal model linking proactive personality and career success, Personnel Psychology 54(4): 845-874. doi: https://doi.org/ 10.1111/j.1744-6570.2001.tb00234.x. 
Shondrick, S. J., Dinh, J. E., and Lord, R. G. (2010). Developments in implicit leadership theory and cognitive science: applications to improving measurement and understanding alternatives to hierarchical leadership, The Leadership Quarterly 21(6): 959-978. doi: https://doi.org/ 10.1016/j.leaqua.2010.10.004.

Shondrick, S. J., and Lord, R. G. (2010). 'Implicit leadership and followership theories: dynamic structures for leadership perceptions, memory, leader-follower processes.' in Gerard P. Hodgkinson and J. Ford (eds.), International Review of Industrial and Organizational Psychology 2010 Volume 25. doi: https://doi.org/ 10.1002/9780470661628.ch1.

Skogstad, A., Einarsen, S., Torsheim, T., Aasland, M. S., and Hetland, H. (2007). The destructiveness of laissez-faire leadership behavior, Journal of Occupational Health Psychology 12(1): 80-92. doi: https://doi.org/ 10.1037/1076-8998.12.1.80.

Strauss, A. L. 1987. Qualitative Analysis for Social Scientists. New York: Cambridge University Press.

Styhre, A. (2010). Knowledge work and practices of seeing: epistemologies of the eye, gaze, and professional vision, Culture and Organization, 16(4): 361-376. doi: https://doi.org/ 10.1080/14759551.2010.519931.

Sutcliffe, K. M., and Weick, K. E. 2008. 'Information overload revisited.' in Gerard P. Hodgkinson and William H. Starbuck (eds.), The Oxford Handbook of Organizational Decision Making, Oxford, UK: Oxford University Press.

Sy, T. (2010). What do you think of followers? Examining the content, structure, and consequences of implicit followership theories, Organizational Behavior and Human Decision Processes 113(2): 73-84. doi: https://doi.org/ 10.1016/j.obhdp.2010.06.001.

The Telegraph. (2015). 'How Sweden became the startup capital of Europe.', Accessed January 22, 2016. Available at: http://www.telegraph.co.uk/finance/newsbysector/mediatechnologyandtelecoms/11689464/How-Sweden-became-the-startup-capital-of-Europe. html.

Thomas, J. P., Whitman, D. S., and Viswesvaran, C. (2010). Employee proactivity in organizations: a comparative meta-analysis of emergent proactive constructs, Journal of Occupational and Organizational Psychology 83(2): 275-300. doi: https://doi.org/ 10.1348/096317910X502359.

Tynell, J. (2002). » Det er min egen skyld «-nyliberale styringsrationaler inden for Human Resource Management ('It is my own fault' - neoliberal control rationales in HRM), Tidsskrift for arbejdsliv 4(2): 7-24.

Wall, T. D., Cordery, J. L., and Clegg, C. W. (2002). Empowerment, performance, and operational uncertainty: A theoretical integration, Applied Psychology 51(1): 146-169. doi: https://doi.org/ 10.1111/1464-0597.00083.

van Dierendonck, D. (2011). Servant leadership: a review and synthesis, Journal of Management 37(4): 1228-1261. doi: https://doi.org/ 10.1177/0149206310380462.

Weick, K. E. (1993). The collapse of sensemaking in organizations: the Mann Gulch Disaster, Administrative Science Quarterly 38(4): 628-652. doi: https://doi.org/10.2307/2393339.

Weick, K. E. 1995. Sensemaking in Organizations, London: Sage.

Weick, K. E., Sutcliffe, K. M., and Obstfeld, D. (2005). Organizing and the Process of Sensemaking, Organization science, 16(4): 409-421. doi: https://doi.org/ 10.1287/ orsc. 1050.0133.

Wrzesniewski, A., and Dutton, J. E. (2001). Crafting a Job: Revisioning Employees as Active Crafters of Their Work. doi: https://doi.org/ 10.5465/AMR.2001.4378011. 